\title{
Ras Kimono, the Relics of Slavery and the African Diaspora: A Study on the Socio-Cultural Factors in the Haitian-Biafran Relations
}

\author{
Ibenekwu Ikpechukwuka E. ${ }^{1}$, Uche Uwaezuoke Okonkwo ${ }^{2}$ \& Efobi Ifesinachi ${ }^{3}$ \\ ${ }^{1} \mathrm{PhD}$, Research Fellow, Institute of African Studies, University of Nigeria, Nsukka. \\ Email: Ikpe.ibenekwu@unn.edu.ng \\ ${ }^{2}$ Senior Lecturer, Department of History and International Studies, University of Nigeria, Nsukka. \\ Corresponding Author. Email: ucheokonkwo2007@yahoo.com. \\ ${ }^{3}$ Graduate, Department of History and International Relations, Ebonyi State University Abakaliki. \\ Email: Efobi111@gmail.com
}

\begin{abstract}
It is no longer news that people of African descent were enslaved to the new world via: Caribbean, America and Europe for more than four hundred years. Rastafari movement has always engaged in the history of memory especially to reminiscence about slave experiences. Bob Marley songs are replete with such freedom chants. For example, Marley's Redemption song and Buffalo Soldier are strong lyrics about the horrors of slavery. The cultural linkage between the Igbo of Southeastern Nigeria and Haiti in the Caribbean is examined, especially the nexus between Trans-Atlantic Slave Trade and the Haitian support to the Biafran struggle during the Nigerian Civil War 1967-1970 re-echoes the African slave narratives as Kimono recorded in his song.
\end{abstract}

\section{Keywords}

Ras Kimono, Slavery, African diaspora, Biafra, Trans-Atlantic Slave Trade, Nigerian Civil War

\section{Introduction}

In his debut album titled Under Pressure, Kimono's Slavery recreates a deep emotion about African freedom narratives. While Kimono embarked on historical search of those horrific years, this chapter strongly believes that African connections with the Diaspora could make a lot of sense in terms of meaningful development that can aid Africa. The 1989 Kimono's album produced by Premier Records was a defining moment in our comprehension of African Diaspora studies. Kimono Slavery Days reads in part:

$$
\begin{aligned}
& \text { I ni I suffer for Slavery Days } \\
& \text { I ni I suffer for Slavery Days }
\end{aligned}
$$


They took us away from Ethopia

They took us away from Nambia

They took us away from Liberia

They took us away from Nigeria

The movement and displacement of able-bodied youths from their homes was the greatest set back witnessed in Africa since the dawn of human existence. This is because these able-bodied youths if not displaced and sold into slavery, would and should have contributed in Africa's development. Walter Rodney in book How Europe Under Developed Africa expresses similar view about the root causes of Africa's backwardness. Kimono's Slavery Days a kind of rekindled global conscience about the ills of slavery and the album Under Pressure was released during the period Africa was trying to make a case for Reparation as a kind of compensation for the lopsidedness created by the imbalance in Afro-European relations vis-à-vis the slave trade and colonialism.

Significantly, the Diaspora influence especially Haiti's support for Biafra is re-examined in this chapter for the purpose of establishing ancestral and cultural linkages in international politics. The reference to Igbo ex-slaves is of great importance to this study considering the significant impact made by Haiti in supporting the Biafran struggle especially since the Igbo constitute the largest ethnic group among the secessionist groups from Nigeria. The struggle for Haitian independence demonstrates a basis to acknowledge that such resistance spirit can be found among the Igbo people of southeastern Nigeria. This led us to the popular Igbo landing also written as Ebo (Igbo) landing. History has it that in May 1803, a shipload of seized West Africans, upon surviving the middle passage, knee landed by the US paid captors in savannah by a slave ship named Rose. Demographic loss of the Igbo resistance in the Ebo landing is uncertain, but the mutiny carried out by the Igbo people is on record as the first freedom march in the history of America. (Imorou .2017:51) Besides the Igbo slave resistance in America, the Haitian Revolution of 1789 to 1804 in Saint Dominique has been widely accepted as the First Black Emancipation Movement in the Diaspora. (Ogen. 2009:187)

It is a movement (Haitian Revolution) not separated from the Igbo resistance spirit. During the period in the discourse, Olaudah Equiano an Igbo ex-slave wrote his interesting narrative suggesting in many ways the relationship between the Igbo and the outside world vis-à-vis the trans- Atlantic slave trade. His publication, which came up in 1789, is an eloquent testimony of the enduring and the resistance spirit of the Igbo especially their quest to be free at all cost.(Jones 1967:60 - 69)

The Nigerian Civil war serves in no small measure as a reference point to re-echo the Igbo resistance spirit, which manifested in the Haitian revolution already mentioned. This research explores the interconnectedness between Haitian and the Igbo in its quest to unravel the support of the Haitian government to the Biafran struggle. Douglas B. Chambers Enslaved Igbo and Ibibio in America: Runaway Slaves and Historical Descriptions are a carefully documented series of Igbo runaway slaves in America's. The book critically analyzed the place of Igbo people in the resistance struggle in Haiti and in Diaspora in general. The Igbo slave, according to the book is known for 
their pride and would prefer the option of committing suicide rather than being enslaved (Chambers, 2013)

Okon Edet Uya's African Diaspora and the black experience in the new world slavery is thought-provoking. (Uya,1987). The writer showcases Afro-American experience during the slave trade, especially in the areas of cultural adaptability designed by the slaves in order to meet up with challenges posed in the new world. Furthermore, the book provides an update to our understanding of slave resistance, religion, emancipation movements, and black settlements. Like Chambers, the writer offers the relevance of Igbo people with regard to the development of Haiti. Next to Uya is Otoabasi Akpan's paper on the Nigeria and the blacks in the Diaspora (Akpan, 2005, 426-440). The paper attempts a critical analysis of the blacks in the new world as discussed by other scholars. However, of great importance to the present study is the author's insistence that blacks in the Diaspora should assist in the quest to develop their home countries. The author argues that the abolition of the slave trade in 1807 could not end the trade in slave. In addition, M. Ron Karenga's "Relations between Africans on the continent and Africans in Diaspora", accounts for the need for Africans at home to learn about the contribution of Africans in Diaspora such as Dubois, Garvey, Padmore, Blyden and others (karensa 1977,88-93

This point has been strengthened by Patrick Manning in his call to strengthen research interest in Africa and the African Diaspora (Manning, 2007) Henry Louis Gates, Jr. and Elizabeth Isichei's have shown revelations of the Igbo sojourn to the new world using Olaudah Equiano as the unit of analysis. Their works offer useful insight that will assist our analysis in this research. (Henry Louis Gates, 1987: 3-88 and Isichei, 1976). In the Nigeria civil war literatures, very little emphasis is made on the Nigeria - Haitian relations. Hence, some of them are reviewed here. Olusegun Obasonjo's My Command is one of such books. An interesting personal experience as a war veteran made little reference to the Haitian support of Biafra by Doc Duvalier as irrelevant and of no consequence (Obasanjo, 1980)

Chinua Achebe's There Was A Country is thought revealing and represents what could be considered as an eyewitness account of the life and challenges in Biafra. The author's revelation of the injustices against Biafra demonstrates how baseless the claim in many quarters that it was the Igbo greed that led to the Nigerian civil war. Interesting is the author's ability to capture Haitian interest in Biafra marked the full diplomatic recognition by a non-African nation (Achebe, 2012 , 99). All the literature reviewed attempt in a concise manner to mention in passing about the Nigerian-Haitian relations. Hence, the lacunae in previous scholarship will be analyzed critically to see how Haitian - Igbo relations forms the challenge of the present study.

\section{Haitian-Nigerian Relations}

The Foreign domination of Haiti was altered by the slave revolt of 1804 . As a slave society, Haiti witnessed all forms of human degradation associated with every oppressed society. However, as a society comprising people of several backgrounds, the resistance offered by the Haiti slaves is a reference point for historical discourse. The Haitian society was a slave colony society. This shows that the legacies of the slave trade, especially ex-slave from Nigeria were part of the numerous blacks drawn from all over the world in order to build an agrarian society in a Caribbean Island. 
Nevertheless, a critical appraisal of the voyages of the trans-Atlantic slave trade shows that there were cultural and psychological behaviour of the Nigerian slaves, especially the Igbo slave that were exported to the new world.

Geographically, the two countries are not neighbours. The relationship between the two countries is deep rooted in the era of the trans-Atlantic Slave trade. The trans-Atlantic slave trade actually started even before the voyage of Christopher Columbus in 1492. To justify this view further, Offiong wrote that:

The Atlantic Slave trade started some 50 years before Columbus voyage to the Western World. The trade started with Europeans invading the coast of Africa and capturing its inhabitants for sale on European markets, especially, at the initial stage, in Portugal and Spain. According to the earliest record of slave-catching kept by Azuara, leader of a Portuguese Venture in 1446, after his ship had landed on the West Central west of Africa, Soldiers swarmed ashore, seized a few curious and unsuspecting natives and proceeded in land seeking more victims. (Offiong, 1980, 86)

The slave trade has a lot of evidence to ascertain that Nigerian slaves more especially the Igbo slaves supported by Haiti during the Nigerian Civil War and Constitutes greater percentage of the population of the Caribbean countries. Douglas Chambers remarked, "the French slave trade to the sugar Island of Saint Domingue (Haiti) was so huge before the Haitian revolution erupted in 1791 that Biafran Africans were also taken there in some numbers. Though only a small percentage of the saint-Dormingue slave trade (less than 10 percent), about 30,000 or so Biafran Africans- mostly Igbo-were transported in just one generation (C 1770-1790) where they influenced the development of Haitian Vodun (Voodoo)."(Chambers, 2013:5).This view has been justified further by Okon Uya who stated that old Calabar, Borons, Elem Kalabari, and Ikot Abasi, the principal ports of the region, drew most of their slaves from the densely populated Ibibio and Igbo people" (Uya 2012, 243)

This assertion thus assists in so many ways to set aside Professor Ogen Koya's Claim that:

The historical development of Black African slaves of Haiti from French colonial servitude was in no small measure aided by an appeal for help to the well-known Yoruba deity, particularly Ogun, the god of Iron and war. In Egun dialect of Yoruba Language, Voodoo can be translated as Almighty God, the overall supreme Diety. Ogun, the god of Iron and war is regarded as man's ultimate mediator with voodoo in times of civil conflict and war. (Ogen 2009: 185)

There may be elements of slave resistance emanating from Yoruba cultural background but certainly, the Yoruba did not constitute the major ethnic group that dominated the slave society in Haiti. Professor Robin law wrote that: "despite the reputation of Igbo slave in the America's for docility (or more precisely, for expressing their disaffection through suicide rather than rebellion), it seems quite likely that it was the Igbo form of blood-oath which was utilized in some recorded slave insurrections. The conspirators in Jamaica in 1816 seem to have been predominantly Igbo, since they proposed to elect a king of the Eboes as their leader. It also seems possible that the blood oath reported in Tackey's conspiracy in Antigua in the 1730's had an Igbo 
origin", since Igbo were relatively numerous among the misplacement of the Igbo people into the trans-Atlantic slave trade has been adequately over flogged. (Law, 1999:14).

Isichei has it on good record that between 1786 and 1800, a total of 26,000 slaves sold in Bonny had 16,000 as Igbo and over a period of twenty years, about 320,000 Igbo's had been sold into slavery at Bonny (Isichei, $1976: 43$ ). The number of Africans sold to the new world was of great concern to Ras Kimono. Although he did not attempt to provide demographic evidence of the actual number of Africans involved during slavery, yet he added a voice:

They made us to work so hard in the plantation

They gave us heavy marks on our backs

We language is prohibited over there

Me say me language is prohibited down there

\section{I ni-I suffer for slavery days(31ce)}

They took us away from Gold coast

They took us away from Ivory Coast

They took us away from Congo

Me say they took us away from Soweto

\section{Oh lord I ni-I suffer for slavery days(31ce)}

They beat us

They kill us

They use us

Until dema refuse us

But we will never forgot the agony

They still lingering in our soul

The slave resistance in Haiti and some other place in the Caribbean cannot be properly understood if effort is not made to understand the slave identity in the new world especially among the Igbo. For instance, while slaves working in various plantations in the Caribbean and Europe were given English names, there was still evidence of the ethnic identification in addition that slaves bore such names as Ebokaty, Ebo mary, Ebo Nancy signifying slaves of Igbo (Eboe) extraction. (Uya, 1987, 108). It could be against this background that Isichei observed as follows:

In the New World, the Igbo did not take kindly to servitude, and were unpopular among planers for this reason. Some preferring death to captivity, tried to commit suicide, although, in the words of one planer "if their confidence be once obtained, they manifest as great fidelity, attention, and gratitude as can reasonably be expected from men in a state of slavery. Another source gives us a glimpse of Igbo slaves in Haiti, excellent for works in the field yet difficult to manage. They kept a strong sense of their Igbo identify and gave help, care and instruction to new arrivals from Igbo land. (Isichei, 1976:44 ) 
Be that it may, the Igbo slaves were referred in the new world asEboe. This is a view that has been adequately taken care of by Olaudah Equiano in his interesting narratives. According to him: "the West India planters prefer the slave of Benin or Eboe, to those of any part of Guinea for their hardiness, intelligence, integrity and zeal." (Gates, 1987, 17).This claim does not in any way serve as an excuse for the Igbo slaves, each time they had the opportunity to revolt.

\section{Beyond The Haitian Revolution}

The Haitian revolution of 1804 was an outcome of a slave revolt. As already, emphasized, greater percentages of these slaves were Nigerian slaves and predominantly Igbo slaves. According to Chambers, the Igbo were the great majority of people enslaved from the hinterland of the Bight of Biafra. Although the so-called Moco, Bibi (Ibibio), and Calaba/Calabali (Calabar), were also enslaved in some numbers. Overall, it appears from Diaspora records that the Igbo were something like 70 to 75 percent of enslaved Biafran Africans. Of a sample of 2,128 Biafran Africans in various kinds of Diaspora records, including runaway slave advertisements, from a wide selection of the New World from South Carolina and Louisiana in North America, to Jamaica, Saint Domingue and, Guadeloupe in the West Indies, some 1,504 or 71 percent were described as Igbo. (Chambers,2013:7). It was the failure of the red Indians brand of slaves. In song titled Kimono they Want, he had this to say:

They don't want Yellowman

They don't want Channel Man

Ah just Pure African man dema want

The Haitian revolution was led by Toussaint Louvertue in 1791. By 1804, Haiti had their independence. This was a great success for it recorded the first republic of blacks in the Diaspora. Haiti became the major symbol of the ability of slave to overthrow the system and get their freedom (Uya, 1987: 162). The beginning of Nigeria-Haiti relations could be traced to the TransAtlantic slave trade, which resulted in the loss of able-bodied men and women of Africa to the New World. As established, the resistance spirit of the Igbo ex-slaves was made manifest with the Haitian revolution of 1804 . Furthermore, the Igbo slaves that were part of the Haitian support for Biafra were known to be committed to duty and hardworking, a view already justified in the interesting narrative of Olaudah Equiano. Be that as it may, the Igbo pride, culture and heritage of pride accompanied the Igbo slaves to the new world and to a large extent helped in building their nationalistic spirit.

Foreign interests during the Nigerian Civil War have been of keen interest to many authors and researchers. However, in this study, the Haitian interest on the Nigerian Civil War is the focus of the present study. The foreign interest in the Nigeria-Biafran war comprises state and non-state actors. In Africa, some of the state that supported Biafra included Gabon, Tanzania, Zambia and Ivory Coast. Some of the powers that supported either side (Biafra or Nigeria) included France, US, Britain, Germany, Czechlovakia, Haiti and others. It will not be necessary to elaborate the support of these groups in details. Non-state actors in Biafra-Nigerian struggle included Caritas, World Council of Churches (WCC), Red Cross, and American Jewish Relief Association (JRA), just 
to mention but a few. Kimono captured the horrors of the war from his childhood experiences in West Niger Igbo and post war civil disobedience. According to him:

$$
\begin{gathered}
\text { Oh Jah see them coming } \\
\text { Police are shooting } \\
\text { Innocent People } \\
\text { What a pity in our city }
\end{gathered}
$$

The shooting of defenseless people especially Civilian populace was part of the bitter horror of the Nigerian Civil War, yet the Super powers could not classify such development as genocide. The support given to either Nigeria or Biafra was done either for economic, ideological, religion, historical or bilateral reasons. Support was also given on compassionate grounds especially because of the suffering of women and the Church in Biafra. As little as these supports appeared to be, they succeeded largely in elongating the War. This could be understood on the several resistances put up by the Federal Military Government (FMG) which included attacking aircrafts conveying relief materials to Biafra.

Non state actors played significant roles during the Nigerian Civil War. The Church (this includes denominations such as the Roman Catholics and the Protestants) understood the Biafran struggle and thus got involved with the project of survival. This is understandable in view of the fact that Christian Missionaries have become part and parcel of the traditional humane living of the people. According to Anyanwu:

In every sense the Churches saw the Biafran case as challenge to their Christian prescience. Many in the clergy joined the army as chaplains. It was at the international area that the churches in Eastern Niger made it quite clear that they were convinced of the justice of the Biafran struggle. Thus, in the face of the overwhelming diplomatic and other obstacles from powerful nations like Biafran, the churches were able to attract the attention and sympathetic involvement of the leadership of the world church. As a result, the envoy of the pope visited Biafra on 17 th February, 1968 (Anyanwu, 1999:128)

The role played by the Christian Missionaries at the international scene during the hit of the Nigerian Civil War yielded positive results but not without its challenges. For instance, it is on record that in June 1969, the Federal Migs shot down an international Red Cross relief plane killing its crew of four. This made the organization passively neutral suspending its activities. The other organizations, led by Joint Church Aid and Caritas consistently ignored Federal Government of Nigeria disapproval. (Uwechue,1971:10). A letter written to the American Jewish Committee recorded thus:

In response to this tragedy, Catholic Relief services has made available 34 air shipment, of food and medicine to Biafra and to the victims in the federal side during the past few months, the international Red Cross has sent in 16 shipments; and the World Council of Churches has sent in 8 shipments as the WCC meeting which closed in Uppsala on July. The WCC committed that to raise three million Dollars in food, medicine and monies (JCA, American Jewish Committee July 22, 1968) 
The appeal for relief in Biafra started since 1968 with the fall of Enugu and most importantly Abakaliki which served as the foods supply centre of Biafra. Hence, Caritas Internationalis began Sao-Tome Biafra Airlift in February 1968. (Davis,1975:506) Before this period, the role of the Catholic Church in relief operations had already been perfected. It is on record that "Bishop Whelan of Owerri Catholic Ecclesiastical Province was made Chairman of the welfare Department of the Eastern Nigerian Bishops conference on 20 April 1967. In that capacity, he worked closely with the Rehabilitation Commission Established in 1966 by the Eastern Nigerian Government for victims of the pogroms. Hence, until the Caritas and WCC Airlift to Biafra was properly set up in 1968, Whelan choose to distribute all relief materials that were sent to the Catholic Church through the government Rehabilitation Commission. (Omenka,2013: 65). His interest in Biafra was not without severe punishment at the end of the Nigerian Civil War in 1970.

The relief supply to Biafra was largely misunderstood by the Federal Government of Nigeria. Nwoko noted that it was the urgent need to address what they considered as human tragedy that made the International Committee of the Red Cross (ICRC) to come to the Biafra's aid.(Cervenka, 1972:137).The Federal Military Government accused OXFAM (Oxford Committee of Famine Relief) and CARITAS (Charitable Organization of the Roman Catholic Church) of supplying arms to Biafra and went further to insist that they wanted airlift during the day, as night flights, according to them, facilitated the supply of arms to Biafra.(Nwoko,2010:37). Obasanjo wrote that:

Capt. Gbadamsi king of the Nigeria Air force shot down, on 5 June 1969, an aircraft which had been apprehended and which refuse to land when asked to do so. This aircraft was not flying within the approved corridor at approved time. The international Red Cross later claimed ownership of the aircraft. The entire crew was killed and non-relief materials were picked up among the wreckage of the aircraft (Obsanjo 1980:165)

This non-relief materials as Obasanjo postulates could imply ammunition to assist the secessionist Biafra in their struggles. This development made the Federal Military Government to prosecute, detain and later expelled twenty-nine Roman Catholic Missionaries in Portharcourt after they were fined 100 Nigeria Pounds each. (Aneke, 2007: 719)·To justify this view further, M.S. Ogbonna wrote that the Catholic Spiritans thwarted the genocidal plan of the Federal Military Government of Nigeria by helping to prolong the war by feeding the Biafra poor. As a result, at the end of the war, the Federal Military Government in retaliation rounded up, humiliated, deported and banned for life about three hundred Spiritans from entering Nigeria. (Ogbonna, 2010:125). This development had great consequences in terms of post-civil war relief distribution in Biafra. The report of two Holy Ghost Fathers in Eastern Nigeria described relief distribution in Biafra as preposterous as federal military government inflated statistics in the amount of food stockpiled. According to them, corruption characterized relief distribution in Orlu, Owerri, Aba and the Uli axis (Declassified PA/HO Department of state E.O 12958 as amended April 21, 2005)

State actors during the Nigeria civil were numerous. In Africa, Biafra was largely affected by the OAU ideological disposition of non- interference in the internal affairs of a member state. Biafrans inability to renounce its sovereignty made the OAU peace effort to fail. However, there was the ideological perception by world leaders that Nigeria's size was a threat. For instance, France was the only European power to give the Biafrans military support as a result of its fear that a united Nigeria would threaten some of its Francophone neighbours. (Nwankwo,2013:505). 
Secondly, France strongly believed in Biafra's quest for self-determination. Furthermore, the president of Ivory Coast Houphouet- Boigny was one of Africans respected leaders and he had an influence on General de Gaulle of France (Holloway, 2015)

For the Soviet Union, there was a marked retrenchment in soviet support for Gowon immediately before the war began. Hence, Russia accused Ojukwu of pursuing tribal separatism under the protection of western imperialism and had already signed a cultural agreement with Gown by March 28 1967, which covered? negotiating for an arms deal. Russia did not frown at the overthrown of Ironsi by Yakubu Gowon. It was a welcome development as far their foreign policy with Nigeria was concerned. (Stent, 1973: 44). Soviet Union understood the plight of the suffering people of eastern Nigeria but endorsed Nigeria's national unity and not secession of any group from Nigeria. Soviet Union understood also the economic base of Nigeria and felt that the crisis was an excellent opportunity to make money in terms of selling ammunition. (Ogunbadejo 1988: 89)

The support of Tanzania, Zambia, Ivory Coast and Gabon to Biafra yielded result. On $13^{\text {th }}$ April 1968, Julius Nyerere of Tanzania felt that the OAU peace effort had failed. He felt that natural justice demanded that Biafra should be supported. His actions led to the increase in assistance given to Biafra in form of arms from donor countries and states such as Israel from the Middle East. Countries such as Yugoslavia, Portugal, Spain, and Czechoslovakia gave support to Biafra towards the end of the Nigerian civil war. (Obsanjo, 1980 :165)

Czechoslovakia authorities criticized the British government for equipping Federal Military government of Nigeria against Biafra. (Orobator,1983: 256) Ireland's support for Biafra has to do with issues of Catholicism. The history of Irish priest congregation in Igbo land is overwhelming and deserves the support of their home country. The outbreak of Nigeria civil war persuaded Dublin to remember millions of Roman Catholics adherents in the Eastern Nigerian enclave. (Staunton,1999: 525) America played the role of neutrality even though greater effort of her foreign policy during this era appeared to have favoured the Federal Military Government of Nigeria. Nevertheless, the British position during the crisis was born out of the conviction to protect the legacies of colonialism, which is to avoid Nigeria's disintegration. Peculiar reasons for embarking on such decision were based on the oil politics, which was controlling the global capitalist system during this period. In addition, the Portuguese were also active participant in foreign aid to Biafra. Portugal used its twin Island of Sao Tome and Principe for major humanitarian relief efforts. It is also assumed that apart from serving as one of the Biafran overseas offices, Lisbon was where the Biafran currency was printed (Osiki, 2010,57)

\section{The Haitian Interest in Nigerian Civil War}

The Haitian interest in the Biafran struggle was as a result of two themes, namely the trans-Atlantic slave trade and Roman Catholicism. For Olusegun Obasanjo, the Haitian support for Biafra was laughable since nobody solicited their support but Biafra (Obsanjo,1980:157) Obasanjo failed to understand the historical ties between the Igbo speaking group of Eastern Nigeria and Haiti. As already discussed, the legacies of the Trans-Atlantic slave trade succeeded largely in shaping 
opinions and ideological positions during the Nigerian civil war. It was against this background that Achebe noted that:

There were other attempts to garner recognition for secessionist Biafra beyond the African continent including wide international one. Those who followed our story were aware of shared history between Biafra and several Caribbean nations, where descendant of former Igbo slaves now lived. That historical connection was employed by Biafran emissions with some success. Biafran diplomatic delegation, led by $\mathrm{Dr}$ Okechukwu Ikejiani and Mr Chukwuma Azikiwe, met with Dr Francois Duvalier, president of Haiti, at the presidential palace in port-au-prince in February 1969. Following that visit, on March 22, 1969, Biafra secured the only non-African, full diplomatic recognition from the Haitian people. 43(Achebe,2012,99)

The entrance of Haiti in 1969 in support of Biafra during the period of the Nigerian Civil War was important for various reasons because it served as the only interactions support for Biafra from a Caribbean country. Second, it helps to elucidate the claim of old ties between the Igbo people and Haiti because of the trans-Atlantic slave trade. These ties were exemplified by the moral support received from Haiti in support of the secessionist Biafra. Furthermore, Haiti is mostly Catholics and Catholics dominates the Eastern region and the Biafran leader C. Ojukwu himself was a Catholic. This further aroused the interest of the Haitian leader Dr. Francois Duvalier also known as "Papa Doc." One of the remarkable lessons from this paper is to note that blacks in Diaspora can assist their home country in a manner to demonstrate belief in old traditional and historical values, legacies and customs. The Nigerian Civil War served as a theatre of such historical reflection as well as the Igbo acceptability in Catholicism in its earlier times in Eastern Nigeria

Suzanne Cronje in his book The World and Nigeria described Haitian support of Biafra on 24 March 1969 as quirk. (Cronje, 1972:300). Whatever forms the opinion of this writer, one thing is certain, many authors on the Nigerian Civil War concur to the fact that international sympathy of the civilian sufferings in Eastern Nigeria triggered Haitian support for Biafra (Uwechue,1971:9). Furthermore, the Haitian interest in Biafra could be as a result of the Roman Catholic domination of the area. John Stremalu in his attempt to interpret the diplomatic relations accorded to Biafra asserts as follows:

no other African government ever joined the four in openly supporting Biafra and the only non-African state to extend diplomatic recognition was the tiny Caribbean country of Haiti. Why president for life Duralier decided in march 1969 to intervene is unclear. The action was taken after a series of informal contacts between Haitians living in the United States and members of former president Azikiwe family. According to Ojukwu, when his representatives finally visited port au prince, the Haitian leader asked why whether it was true that Biafra was a state under the control of black Roman Catholics and when the delegation acknowledged this, he supplied sand "all night" I will recognize you. (Stremalu, 1970,141)

The Haitian interest in Catholicism is comparable to that of the Igbo in terms of the demographic configuration of their respective congregations. For example, in spite of the Christian Missionary Society (CMS) early presence in Onitsha by 1857 the RCM late arrival to Igbo land in 1885 still took control of Igbo towns such as Obosi, Ossomari, Nsugbe, Umuoji, Atani, 
Odekpe and Nkwerre within a short time frame (Obi,1985:24). Beginning from this era, the activities of the Roman Catholic Mission (RCM) got spread into Igbo hinterland and exceeded that of the Christian missionary society (CMS). The RCM activities in Igbo land continued to flourish until the outbreak of the Nigerian civil war in 1967 and beyond.The activities of the various Christian organizations and relief agencies such as the International Red Cross, OXFAM, and CARITAS succeeded to elongate the war by supplying food and drugs to sustain the war in the midst of extreme difficulties.

\section{Conclusion}

The Slavery Days by Ras Kimono as seen in this chapter makes an insight on the nature and dimensions of slave connections. This paper examined the various vexing issues that necessitated the Haitian support for Biafra. The foundation of the Haitian support for Biafra was traced to the trans-Atlantic slave trade which saw to the demographic displacement of able-bodied men and women who could have developed Africa. Ras Kimono lyrics on slavery depict the African terrible experience of its dark history which is the Trans-Atlantic slavery.

As shown in this research, many African scholars such as Offiong, Rodney, and Inikori just to mention but a few have attempted critical analyses of the actual number of slaves involved in the voyage (middle passage) to Europe and the Americas. In this research, attempts were made to show that inter-group relations may not primarily arise from trade contacts but probably by other social factors such as the slave trade. Hence, this has been buttressed by Professor Ade Ajayi who wrote as follows:

The historians may be producing socially relevant history, but they have failed to make society be aware of this. Unlike the traditional historians, the academic historians are out of touch with the masses and have little or no social relevance and yet the traditional historians are limited by language and historical perspective to ethnic history (Ajayi, 1977:39)

Social history as noted by Ade-Ajayi can receive the necessary applause it deserves if historians are encouraged to delve into this area of useful enterprises worth of scholarly experimentation. In this study, the record of the middle passage, the life of resistance, and culture exhibited by the Igbo and other African groups has been widely discussed. Most discussed in relation to the Haitian revolution which marked the beginning of the first black republic in the Caribbean was the fact that the Igbo slaves' desire for freedom must have increased as the ship drew further to the African coast. Hence, thoughts of lost family, friend, and freedom combined with sweltering stench of the fifths hold to produce a variety of reactions. ${ }^{48}$ (Ajayi, 1977:39)

The Igbo slaves preferred to commit suicide in most cases as shown in this study rather than serve in slave plantations. On the other hand, they bought their freedom as shown in the case of Olaudah Equiano who wrote his interesting narratives in 1789.

Also highlighted in this study, is the state of Africa as a result of the evil trade in slaves. According to Offiong: 
Between the $15^{\text {th }}$ and the $19^{\text {th }}$ century, the African continent lost, in enslaved and killed, between 65 and 75 million people, and these were the most vital part of the population, since the aged, the large, the sickly were not among those affected. (Offiong, 1980:41)

Moreover, efforts were made to suggest that the Haitian interest during the Nigerian Civil war was as a result of large Igbo population of ex-slaves domiciled in Haiti. Chambers recorded that in 1759 that there was 77 runaway Biafran African slaves (67 Igbo) in South Carolina and Georgia, and 371 runaway Biafran Africans (including 209 Eboe) in eighteenth- century Jamaica as well as 372 Biafran African runaways (of whom 329 were Ibo) in the eighteenth century Haiti (SaintDomingue) (Chambers, 2013:16). This helps to buttress the claim that it was the Igbo ex-slaves that dominates the Yoruba or any other group as claimed.

Our focus on the Nigeria Civil War suggests that a lot of factors led to the crisis. There was the census crisis of 1962/1963, the 1964 General Election crisis, the Western Region crisis between S.L. Akintola and Chief Obafemi Awolowo, the first military coup, personality crises between Gen. Yakubu Gowon and Col. Odumegwu Ojukwu and the failure of the Aburi Accord, which finally led to the Nigerian Civil war. The Biafran struggle called for international assistance. In Africa, Zambia, Ivory Coast, Tanzania and Gabon offered their support at a period of serious non-interest by other African states about the Biafra agenda. In fact, France and other European countries gave support to Biafran but not fully. Non-state actors such as the CARITAS, World Council of Churches (WCC), and other relief agencies stood by Biafra during the trying times by supplying constantly relief materials.

\section{References}

Achebe, C (2012). There Was A Country: A Personal History of Biafra, London: Penguin Group

Ajayi, J.F.A (1977). "In Search for Relevance in the Humanities in Africa"' in A.U Iwara and E. Mveng. ed. Colloquium on Black Civilization Proceedings, Lagos: Federal Ministry of Information 1977,39

Akpan, O. (2005). "Nigeria and the Blacks in the Diaspora: Symbiotic Relationships for development" in Ikechukwu Amadi et al ed. History and Citizenship: Essays in Honour of Okon Edet Uya, Calabar: Clear lines publications, 2005,426-440

Aneke, L.N (2007). The Untold Story of the Nigeria - Biafra War, New York: Triumph Publishing

Anyanwu" U.D(1999). Christianity and Political Development in Igboland Eastern Nigeria: Animator or Inhibitor, Journal of the Humanities Vol. August, 1999, 128

Cervenka, Z (1972). A History of the Nigerian War, Ibadan: Onibonoje Press

Chambers, D.B (2013). Enslaved Igbo and Ibibio in America: Runaway Slaves and Historical Descriptions, Enugu: Jemezie Association

Cronje, S. (1972). The World and Nigeria: The Diplomatic History of the Biafran War 1967-1970, Britain: Sidgwick and Jackson Limited 
Davis, M. (1975). "Audits of international Relief in the Nigerian Civil War: Some Political Perspectives" International Organization, Vol. 29. No. 2

Isichei, E. (1976). A History of the Igbo people, London: Macmillan

Equiano, O. (1987). "The interesting narrative of the life of Olaudah Equiano or Gustavus vassa the Africa" in Henry Louis Gates, Jr. ed. The Classic Slave Narratives New York: Penguin Books

From Holy Ghost fathers Kevin Doheny and Kleins to department of state January 17, 1970 "Relief to former Biafran Enclave" Declassified PA/HO Department of State E.O 12958 as amended April 21, 2005

Holloway, J.E (2015). the Biafran civil war: the politics of Hunger and starvation, http:// slaverebellion . org/ndet. Php? Page accessed 10 January 2015.

JCA (Joint church Aid Archives) (1968). From Marc H. Tanenbaum to Moms Abran, Biafran Issues and Background for July 25 Meeting, American Jewish Committee July 22

Jones, G.I. (2013). "Olaudah Equiano of the Niger 1bo"in Philip Curtin. ed Africa Remembered, Madison: University of Wisconsin Press

karensa, M.R. (1977). "Relations Between Africans on the Continent and Africans in Diaspora: History and possibilities" in A.U Iwara and E. Mvenged Colloquium on Black Civilization and Education Vol. I Lagos: Federal Ministry of Information

Law, R. (1999). "On the African Background to the slave Insurrection in saint - Domingue (Haiti) in 1791: Bois Cannian ceremony and the Dohamian Blood Pact" Unpublished paper Harriet Tubman seminar Department of History, York University, Monday,8 November

Manning, P (2007). "Advancing and Integrating Research and Studies in the Interest of Africa and the Africa Diaspora" in Tunde Babawale ed. The place of Research and Studies in the Development of Africa and the Africa in Diaspora, Lagos: Concept Publications Ltd

Nassourou, Imorou, N (2017). "To Walk or to Fly? The Legend of the Flying Africans in Toni Morrison's Song of Solomon and Paule Marshall's Praise song forthe Widow" Research on Humanities and Social Sciences, Vol.7, No.2

Nicolas Ibeawuchi Omenka, N.I(2013). "The legacy of Bishop J.B Whelan: Education, Church and Society" in T.I Okere ed. The Church and Igbo society, Owerri: Assumpta Press,

Nwankwo, G.O. (2013). "The OAU peace efforts in the Nigeria civil war" in P.U Omeje and U.U Okonkwo ed New Perspectives on west African History, Enugu: Madona University press 2013, 505

Nwoko K C. (2010). "Our Agony, Their victory: The Impact of the Nigerian Civil War on the Women and Children in Biafra" in U.D Anyanwu and U.U Okonkwo ed. Perspectives on the Nigerian Civil War, Owerri: Imo State University Press

Obi, C.A (1985). "Background to the Planting of Catholic Christianity in the Lower Niger" in Celestine A. Obi ed. et al, A Hundred Years of the Catholic Church in Eastern Nigeria 1885-1985, Onitsha: Africana Fep Publishers

Obsanjo, O. (1980). My Command: An Account of the Nigerian Civil War 1967-1970, Ibadan: Heinemann Offiong, D.A. (1980). Imperialism and Dependency, Enugu: Fourth Dimension Publishers 
Ogbonna, M.S (2010). "Catholic Missionaries and Relief work in Biafra" in Chima J. Korieh and Ifeanyi Ezeonu ed. Remembering Biafra: Narrative, History and Memory of the Nigerian Civil War, New Jersey: Goldline and Jacobs

Ogen, O. (2009). "Historicizing Africa contributions to the emancipation movements: the Haitian revolution, 1791-1805" in Tunde Babawale ed. etal., Teachings and Propagating African and Diaspora History and Culture, Lagos: Concept Publications Itd

Ogunbadejo, O. (1988). "Nigeria - Soviet Relations 1960-87" African Affairs Vol.87, No.346 January

Orobator, S.E (1983). "The Nigeria Civil War and Invasion of Czechoslovakia" African Affairs, Volume 82 number 327

Osiki, O.M. (2010). "The Nigerian Civil War and External Interest" in U.D. Anyanwu and U.U. Okonkwo ed. Perspectives on the Nigerian Civil War, Owerri: Imo State University Press 2010,57

Staunton, S. (1999). "The Case of Biafra: Ireland and the Nigerian Civil War, Irish Historical Studies Vol.31No.124 Nov.1999,525

Stent, A. (1973). "The Soviet Union and the Nigeria Civil War: A Transfer of Realism", Journal of Opinion Volume 3 number 2

Stremalu, J.I (1977). The International Politics of the Nigerian Civil War 1967-1970, Princeton University Press, 141

Uwechue, R (1971). Reflections on the Nigerian Civil War: Facing the Future, New York: African Publishing Corporations

Uya, O.E(2012). "Indigenous Slavery and Slave trade in the Cross river Region: Akwa Ibom and Cross river State" in David Imbua etal ed. History, culture, Diasporas and Nation building: the Collected work of Okon Edet Uya, Betheda Arbi Press

Uya, O.E. (1987). African Diaspora and the Black Experience in New world Slavery, Calabar: Clear lines Publications 